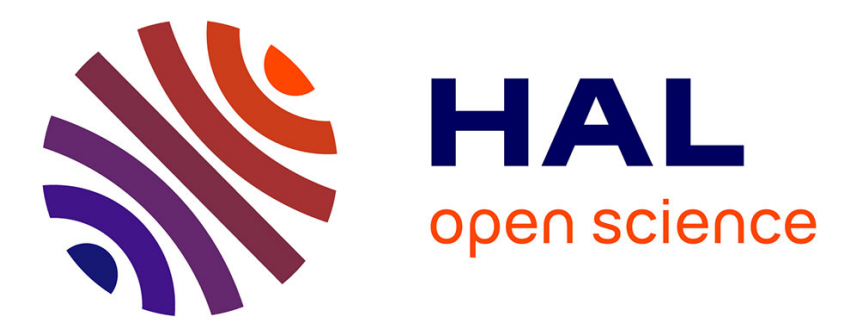

\title{
The (Im)balance of Power. Demosthenes' Complex Case for an Alliance with the Megalopolitans
}

Nicholas D. Cross

\section{To cite this version:}

Nicholas D. Cross. The (Im)balance of Power. Demosthenes' Complex Case for an Alliance with the Megalopolitans. KTĖMA Civilisations de l'Orient, de la Grèce et de Rome antiques, 2019, La rhétorique de la diplomatie en Grèce ancienne, 44, pp.71-85. halshs-02444244

\section{HAL Id: halshs-02444244 \\ https://shs.hal.science/halshs-02444244}

Submitted on 17 Jan 2020

HAL is a multi-disciplinary open access archive for the deposit and dissemination of scientific research documents, whether they are published or not. The documents may come from teaching and research institutions in France or abroad, or from public or private research centers.
L'archive ouverte pluridisciplinaire HAL, est destinée au dépôt et à la diffusion de documents scientifiques de niveau recherche, publiés ou non, émanant des établissements d'enseignement et de recherche français ou étrangers, des laboratoires publics ou privés. 

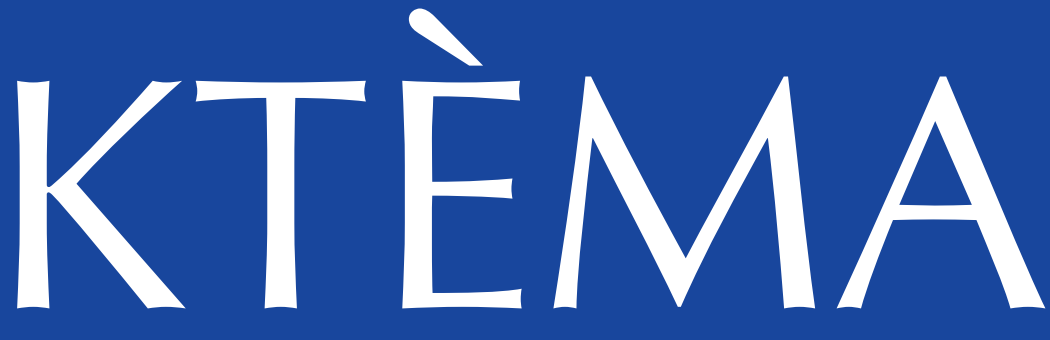

\section{CIVILISATIONS DE L'ORIENT, DE LA GRÈCE ET DE ROME ANTIQUES}

\section{La rhétorique de la diplomatie en Grèce ancienne}

Cinzia BeARzot, Laura Loddo

Laura LoDDo

Cinzia BeArzot

Paolo A. Tuci

Francesca Gazzano

Nicholas D. Cross

Davide Amendola

Jonathan R. W. PraG

Lorenzo CAMPAGNA

Cristina SORACI

Edith Foster

Walter LAPINI

Sylvain PERROT

Gianpaolo Urso

Anne JACQuemin
Political Exiles and Their Use of Diplomacy in Classical Greece

À propos du parallélisme entre deux discours d'ambassade à Sparte (Xén. Hell. V, 2, 12-19 et VI, 1, 4-16). 23

The Speeches of Theban Ambassadors in Greek Literature (404-362 B.C.)................ 33

Greek Ambassadors and the Rhetoric of Supplication. Some Notes ............................ 53

The (Im)balance of Power. Demosthenes' Complex Case

for an Alliance with the Megalopolitans.....

Presbeutikoi and Enteuktikoi Logoi in Hellenistic Interstate Relations.

Some Further Thoughts from an Epigraphical Perspective (c. 306-205 B.C.). 87

\section{Sicile hellénistique et romaine}

I.Sicily, Open Scholarship, and the Epigraphic Landscape of Hellenistic/Roman Sicily.

Trasformazioni urbanistiche in Sicilia alle origini della Provincia.

Riflessioni sul ruolo di Roma.....

Cultes et politique dans la Sicile du i ${ }^{\text {er }}$ siècle av. J.-C.

Le cas de la Vénus Érycine et de la Cérès d'Henna

\section{Varia}

Athens' Political Failures in the Central Chapters of Book 4 of Thucydides 163

Note interpretative e testuali alla col. XXII del Papiro di Derveni

La place de la musique dans la politique culturelle de Téos

dans la première moitié du $\mathrm{II}^{\mathrm{e}}$ siècle avant notre ère

Catilina legatus. Considerazioni su un discusso frammento sallustiano.

La dédicace aux Muses d'Eurydice fille de Sirrhas

(Plutarque, Sur l'éducation des enfants, 20) 


\section{The (Im)balance of Power Demosthenes' Complex Case for an Alliance with the Megalopolitans}

RÉsumé-. Cet article explore les motifs complexes que Démosthène 16 (Pour les Mégalopolitains) présente à l'appui d'une alliance défensive avec les Arcadiens (Mégalopolitains) en 353 av J.-C. En réexaminant tout le discours, l'article conteste que Démosthène donne la priorité à des facteurs politiques, tels que l'équilibre des puissances, et montre qu'il fait appel à divers arguments pour justifier l'interventionnisme. L'article cherche également à comprendre pourquoi les savants modernes mettent l'accent sur le rôle de l'équilibre des puissances dans ce discours, aux dépens de considérations non politiques. Ce discours fournit donc un example qui ilustre la complexité de l' argumentation mise en oeuvre dans la diplomatie grecque classique.

MотS-CLÉS-. Démosthène, équilibre des puissances, relations interétatiques en Grèce ancienne, diplomatie grecque antique, $\mathrm{IV}^{\mathrm{e}}$ siècle grec, historiographie

Abstract-. This article explores the complex motives Demosthenes 16 (For the Megalopolitans) presents in support of a defensive alliance with the Arcadians (Megalopolitans) in 353 BCE. By re-examining the entire speech, the article disputes that Demosthenes prioritizes political factors, such as balance of power, and shows that he uses various arguments to justify interventionism. The article also seeks to understand why modern scholarship emphasizes the role of balance of power in the speech at the expense of non-political considerations. This speech, therefore, provides a test case that demonstrates the complexity of the arguments used in classical Greek diplomacy.

Keywords-. Demosthenes, balance of power, ancient Greek interstate relations, ancient Greek diplomacy, fourth-century Greece, historiography

The first half of the fourth century BCE was a dynamic and volatile period of Greek history, with frequent fluctuations in the leadership positions on the mainland: from the Spartans' contested hegemony in the first quarter of the century to the Athenians' renaissance as a leader of a reconstructed confederacy in the 370s to the emergence of the upstart Thebans after their victory at the Battle of Leuctra in $371 .{ }^{1}$ At midcentury, after decades of jockeying for the position of prominence by the three great powers, the geopolitical structure of the Greek world was in disorder. Far from anyone's mind was the thought that a distribution of power would bring stability. Instead, there was only enough room for one leading state. With that in mind, most of the Greeks, on either the side of the Thebans or of the Spartans and Athenians, met at the Battle of Mantinea in 362, but the outcome was indecisive, a result that was the opposite of what everyone had expected. With no clear winner, the battle failed to realize the hope that it would resolve the arresting ataxia. This led

(1) All dates are BCE. 
the contemporary historian Xenophon to lament that "in Greece there was even more confusion

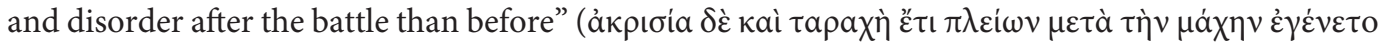

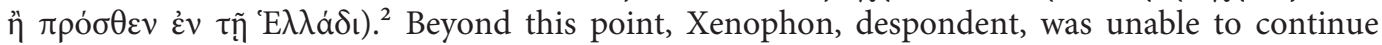
writing his Hellenica.

These destabilizing conditions persisted into the 350s, but the big three found more of the smaller powers abandoning their alliances with them. The Thebans somehow managed to maintain a position of power in southern Greece, though, bereft of the leadership of Epaminondas and Pelopidas, their influence became a shadow of what it once was. They were unable to keep their alliances with the Mantinean-led faction of the Arcadians, Achaeans, Eleans, Phliasians, Alexander of Pherae, and the Thessalians. Their remaining allies eventually deserted them during the Third Sacred War which broke out in $356{ }^{3}$ As for the Athenians, they faced the first years after Mantinea with optimism and aplomb, attracting to their side many of those who defected from the Thebans. These alliances were followed by new ones in the north, with the Odrysian kings in 357, and with the Thracians, Paeonians, and Illyrians in $356 .{ }^{4}$ But this was as far as the Athenians could expect to extend their reach. The new alliances came to nothing, and during the Social War (357-355) many of their Aegean allies successfully revolted from the Second Athenian Confederacy. By the mid350s, the Athenians, like the Thebans, projected a dim reflection of their past greatness.

The Spartans, too, struggled to maintain their alliances. They never fully recovered from their defeat at Leuctra, the subsequent Theban invasions of the Peloponnesus, and the dissolution of the Peloponnesian League. At the beginning of the 350s, when Archidamus III ascended to the Eurypontid throne, the Spartans were in the unfamiliar position of being only a local power. The outbreak of the Third Sacred War, which kept Thebes engaged in central Greece, provided an opportunity for the Spartans to regain their command of the Peloponnesus. Archidamus' initial plan was to recapture Messenia, which had broken free from the Spartans with the help of Epaminondas in 369 and gained a recognition of their autonomy in the common peace agreements of 366 and 362-what Wolfang Will calls a "Rollback-Strategie." But when the Spartans attacked in c. 355, the Messenians found help from the Argives, Arcadians, and Athenians. Rebuffed by this show of support, the Spartan army turned against Megalopolis, the new capital city of their erstwhile Arcadian allies. The Arcadians, however, sought help from the Argives, Sicyonians, Messenians, Thebans, and, as we learn from Demosthenes' speech For the Megalopolitans, the Athenians. ${ }^{6}$

When the Arcadian (Megalopolitan) ambassadors approached the Athenian Assembly and pled their case for an alliance against the Spartans, they found that their attackers had also sent ambassadors to insist that the Athenians respect their alliance from $369 .^{7}$ Demosthenes says that there were certain Thebans in attendance, though it is not known whether they made any contributions to the meeting or were simply silent observers. In the subsequent debate, the Athenians were divided, some speaking in support of the Arcadians and some in support of the Spartans. When it came his turn to speak, Demosthenes, thirty years old, began by distancing

(2) Xen. Hell. 7.5.26-27. Dillery 1995, p. 17-38 discusses Xenophon's judgments on order and disorder in Greece. All English translations are the author's.

(3) Kelly 1980, p. 64-83; BucKler 1980, p. 220-227; Schachter 2016, p. 113-132; Cross 2017, p. 280-303.

(4) The Athenians made alliances with various Peloponnesian states in 362 ( $I G \mathrm{II}^{2} 112$; GHI 41), the Thessalian League in 361 ( $I G \mathrm{II}^{2}$ 116; GHI 44), Odrysian kings in 357 ( $I G \mathrm{II}^{2}$ 126; GHI 47; Dem. 23.170-178), the northern kings in 356 (IG $\mathrm{II}^{2}$ 127; GHI 53; Diod. 16.22.3), and the Phocians in 355 (Dem. 19.61-62; Aeschin. 3.118; Diod. Sic. 16.27.3-5; Paus. 3.10.3).

(5) Will 2013, p. 53. Recognition of Messenian autonomy: Polyb. 4.33.8-9; Diod. Sic. 15.89.1-2; Plut. Ages. 35.3; cf. Ryder 1965, p. 140-144; Jehne 1994, p. 96-115. The Spartan Attack on Messenia: Paus. 4.28.1-2; Dem. 16.9.

(6) The Spartan attack against Megalopolis: Diod. Sic. 16.39; Paus. 8.27.9-10.

(7) The Athenian-Spartan alliance: Xen. Hell. 7.1.1-14. 
himself from the previous partisan cases of his elders and claimed that he would, "without party-

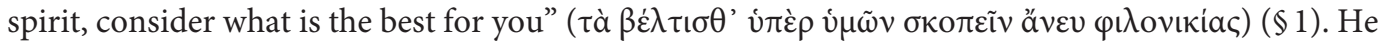

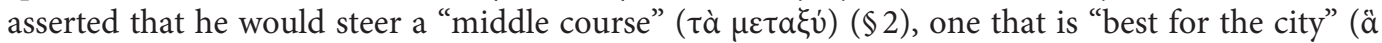

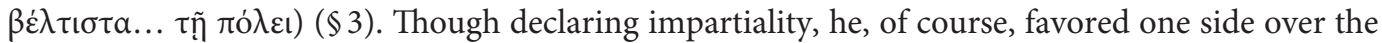
other. That is, he advocated unequivocally for the Arcadian alliance. Although his position is clear, the case he makes for it is packaged within a concoction of assorted points, not at all consistent or coherent with each other.

Although as a young politician he must have been seeking for an angle in the debate that

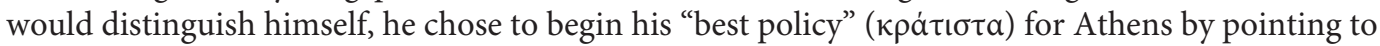

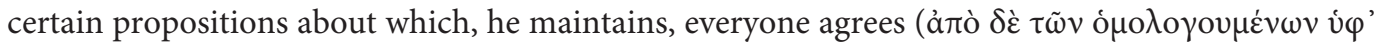

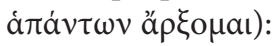

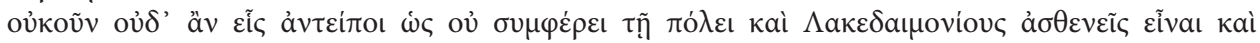

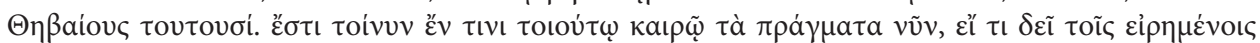

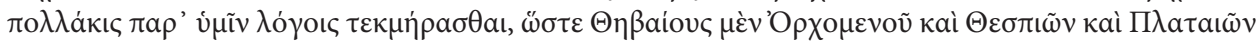

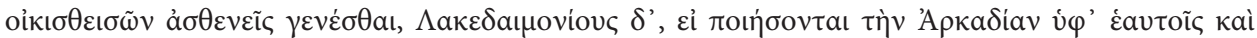

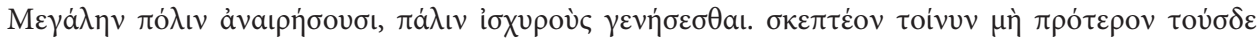

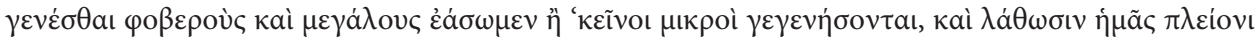

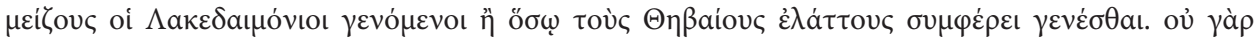

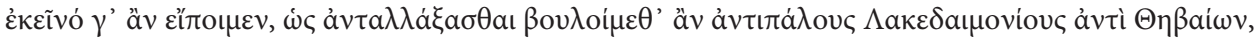

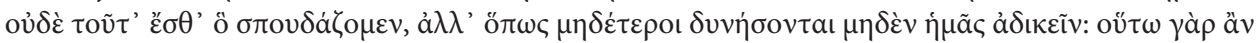

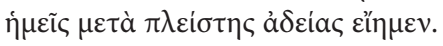

Surely then no one would dispute that it is for the advantage of the city that both the Spartans and these Thebans are weak. Therefore, if one should judge from the words which you have often spoken, the state of affairs now lies in such an opportunity: the Thebans will become weak when Orchomenus, Thespiae and Plataea are refounded, but if the Spartans put Arcadia under their power and destroy Megalopolis, they will become strong again. We must therefore make sure that we do not let the Spartans become fearsome and powerful before the Thebans become weak, or, without our noticing it, let the Spartans become so much greater than it is in our interest for the Thebans to become smaller. For we would not say that we wish to exchange as rivals the Spartans for the Thebans-nor is that what we would pursue, but rather that neither of them is able to injure us. For in this way we would be the freest from fear $(\$ 4-5){ }^{8}$

Demosthenes' reasoning here, prima facie, comes close to what modern political scientists call "balance of power." Although its definition is versatile, by balance of power scholars generally refer to a situation in which one state grows disproportionately and endangers the geopolitical equilibrium, thus forcing those directly threatened by it to enter into a formal military alliance, to obstruct the revisionist state and restore the status quo. ${ }^{9}$ The central aim of states working within an international structure based on balance of power is to preserve a roughly equal distribution of geopolitical power by preventing one state from dominating all the others-a system of checks and balances on power. In this scenario, each state's foreign policy decisions are made on the pragmatic basis of national security concerns and not at all related to matters of morality or ideology. Examples of balance of power include the alignments of the Axis and Allied powers in the two world wars, or the positioning of smaller states with either the USA or the USSR during the Cold War.

Balance of power has been a clear diplomatic goal in modern history, but did the ancient Greeks also understand interstate relations in such terms? Does the above outline of the mid-fourth century geopolitical context reflect a balance of power thinking? In response to this question, many scholars answer in the affirmative and point to Demosthenes 16.4-5 for support, as confirming

(8) On the interchangeability of Lacedaemonia and Sparta, see Ducat 2010, p. 189-196.

(9) On the plethora of definitions for balance of power, see Wight 1966, p. 149-175; SHEeHAN 1996, p. 1-23. 
evidence, stopping short of the rest of the speech. This passage contains a complex plan of forming alliances with multiple small powers in Boeotia and in the Peloponnesus, in order to obstruct the aggrandizement of the larger powers in those same areas, which sounds a lot like balance of power, but the speech, when taken as a whole, does not present such a coherent strategy. Demosthenes does not seek to construct or maintain a balance of power in Greece-something neither he nor Xenophon would have recognized-but rather an imbalance of power, in the favor of the Athenians.

In War, Peace, and Alliance in Demosthenes' Athens, a recent study of the extant speeches delivered in the Athenian assembly of the fourth century, Peter Hunt stresses both the moral and political motives for the alliances of Demosthenes' time. ${ }^{10}$ Likewise, this article reexamines Demosthenes' For the Megalopolitans and proffers an alternative to the general emphasis in modern scholarship on balance of power for the orator's calculus for an alliance with the Arcadians. This article concurs with Hunt's assessment and argues that although power politics played an influential part in the construction of interstate alliances in the fourth-century Greek world, for Demosthenes there was more: he also considered social, moral, ideational, and religious factors. The first section of the article sets aside modern international relations theory-for the strategy of beginning such a study through a preconceived model is fundamentally flawed - and reviews Demosthenes' stated positions on the major players whose fortunes might be altered by the proposed alliance with the Arcadians. Despite his often serpentine and opaque reasoning, Demosthenes' advocacy for the alliance rests on three bases-legal, moral, and political. The second section explores the genealogy of balance of power, seeking to uncover the roots of modern scholarship's focus on power politics at the expense of the other non-political considerations that Demosthenes highlights. The conclusion of this historiographical exploration is that, for the ancient context, balance of power is an anachronistic concept not an ahistorical one. This article's reconsideration of Demosthenes 16 highlights the complexity of the rhetoric employed in classical Greek diplomacy and calls for a new interpretative framework that reflects that complexity.

\section{DEMOSTHENES' ARGUMENTS FOR THE ALLIANCE WITH THE MEGALOPOLITANS}

In this speech Demosthenes shows a clear understanding of contemporary geopolitics. His views on the Spartans, although his most distinct ones of the speech, are quite inconsistent. His first mention of them is in $\$ 4-5$, in which he expresses his wish that they remain in a position of weakness in the Peloponnesus. He follows this with his fear that if the Spartans succeed in recapturing Megalopolis, they will then make another attempt to reconquer Messenia. At this point, he asks his Athenian audience, "ask yourselves, whether you will make your start to resist Spartan injustice with more honor and benevolence-for the sake of Megalopolis or for Messene?"

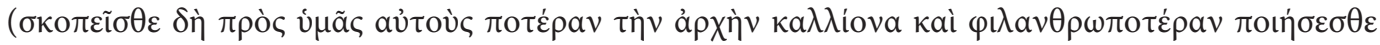

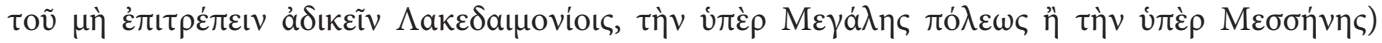
( $\$ 8-9$; cf. 20). This fear, of course, is a practical one: would the Athenians be in a better position defending Megalopolis, before the Spartans enjoy any success on the battlefield, or Messenia, when the Spartans are fresh from victory and optimistic? The answer is the former.

His suspicion of the Spartans, however, briefly changes to confidence that they will not begrudge the Athenians an alliance with the Arcadians. Those in Athens who are opposed to it-the same ones who pushed for the Athenians to defend the Peloponnesus when the Thebans invaded it in 370 and who arranged for an alliance with the Spartans in the following year-had apparently

(10) Hunt 2010. 
threatened the Assembly that the Spartans would attack if the proposed alliance materialized. But when Demosthenes raises those earlier events, when he was but a teenager, he does not see them in the same way. He turns attention to another fateful decision from 370 which resembled that before the Assembly in 353: the Athenians refused aid to a number of Peloponnesian states facing attacks from the Spartan king Agesilaus and thus forced the victims to find help instead from the Thebans. ${ }^{11}$ The resulting alliance increased Theban power at the expense of the Athenians. This had a profound impact on Demosthenes who warns against a repeat of the same situation and yet another lost opportunity. He therefore encourages his listeners to feel anger towards the pro-Spartan faction which once deprived the city of such useful allies and are threatening to do so again $(\$ 19)$. Oddly, however, despite his indignation at the Athenians defending the Spartans, at this point of the speech he imagines that the Spartans would readily allow the new alliance out of gratitude for the Athenians having once helped to defend the Peloponnesus. "And even if we made an alliance with the Arcadians that is wholly against the Spartans' plans, they would, I suppose, have more gratitude because they were saved by us when they were in the greatest danger

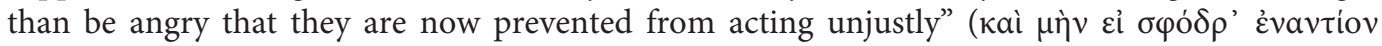

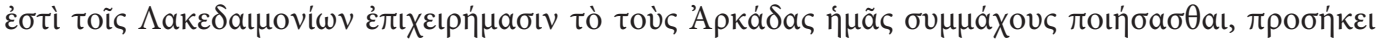

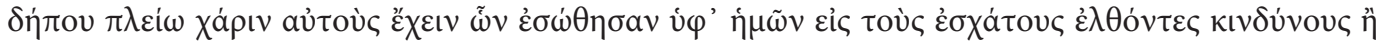

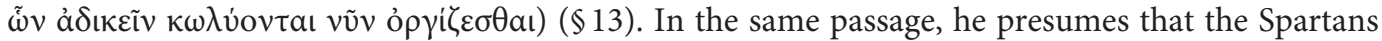
would even support an Athenian attempt to recapture Oropus, a border town between Attica and Boeotia that Thebes seized in 366. "How can they not help us over Oropus, when they would appear

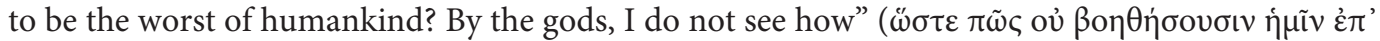

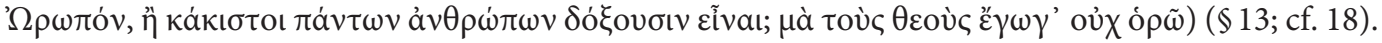
Far from advocating a balance of power, Demosthenes somehow believes that the Athenians can arrange it so that the Spartans, seeing their power further reduced because of Athenian actions, will support, freely, the growth in Athenian power.

But he has little else that is positive to say for the Spartans. He supposes that they back others in their territorial disputes-Elis over Triphylia, Phlius over Tricaranon, and Athens over Oropusnot for reasons of justice but in order to secure support for their own attacks against Messene and Megalopolis (\$16-17). Recounting Spartan acts of duplicity, he becomes so agitated that he reverses his earlier position on Oropus, preferring that the Athenians relinquish claims to it rather than abandon the Peloponnesians to the Spartans $(\$ 18)$. He worries that the Spartans, with recrudescent ambitions, will eventually threaten Athenian security-whatever the Assembly's decision is on the Arcadian alliance (\$27-29). Thus far, his support for the new alliance has been predicated not upon balance of power but upon his wish to obstruct a resurgent Sparta. Although early in the speech he makes a few hopeful remarks about the Spartans, ultimately he is filled with distrust and fear about their designs in the Peloponnesus and beyond. In short, his opinions on the Spartans are tortuous, incongruous, and not consistent with balance of power theory.

Demosthenes' opinion of the Thebans is more obscure. He initially declares in $₫ 4$-5 that it is in Athenian interest that the Thebans become weaker, and to achieve that end, the Athenians should accept the Arcadian alliance. Thereby, the Athenians would redeem the missed opportunity of 370, when they rejected the Peloponnesian appeal and thus allowed an increase in Theban strength $(\$ 12)$. He also supports the resettlement of destroyed Boeotian cities (Thespiae, Orchomenus, and Plataea) which would obstruct the military, political, and economic goals of the Thebans, and, furthermore, by keeping the Thebans occupied in central Greece, would give the Athenians the opportunity to recapture Oropus $(\$ 13,18)$. Later, however, Demosthenes, a future proxenos of the 
Thebans, reverses this position and advocates collaboration with the Thebans. ${ }^{12}$ Brought together by their common Spartan enemy, the Athenians and Thebans had been allies twice before in the fourth century: during the so-called Corinthian War and again in the $370 \mathrm{~s} .{ }^{13}$ It is no surprise, then, that Demosthenes would conceive a scenario in which the two would become allies yet again: "If the Spartans capture Megalopolis, Messene will be in danger: I predict that we will find ourselves

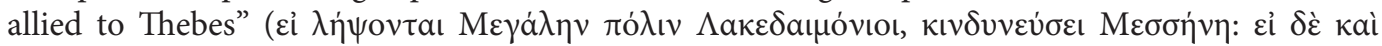

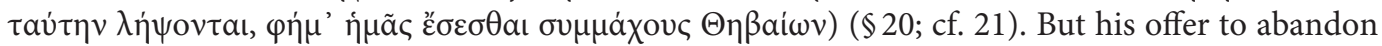
claims to Oropus is only theoretical-it depends on whether the Spartans achieve their goals and destabilize the Peloponnesus.

As things stand at the moment, the Thebans remain an enemy and so in the last parts of the speech, Demosthenes returns to his strategy to weaken their power. Although he is firm that the Spartans are a greater threat to Athenian security than the Thebans are, he repeats his support for the reconstruction of destroyed Boeotian cities and for the defense of any endangered Peloponnesians still allied to the Thebans (\$24-25). Ideally, he wishes that the Thebans, currently occupied against the Phocians in the Third Sacred War, will remove their forces completely from the Peloponnesus. "If the Thebans are defeated, as they ought to be," he hopes, "the Spartans will not be stronger than they should be, having these Arcadians, their close neighbors, as opponents"

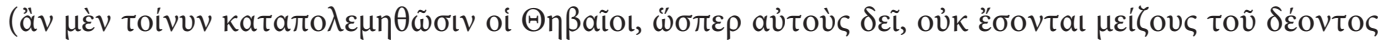

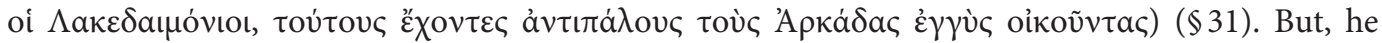
adds, the opposite case for the Thebans makes no difference for Athenian prospects, except in that their weakness allows the Athenians to play their cherished role of defender. "But if the Thebans should recover and be saved, they will still be weaker, because these [Arcadians] will have become

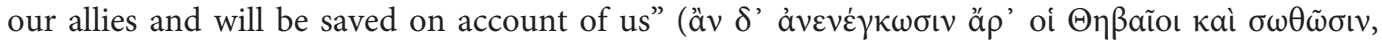

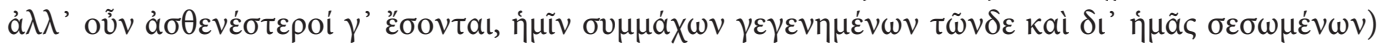
$(\$ 31)$. Throughout the speech, he expresses positions that fluctuate between fear of and preference for the Thebans. Nowhere is there any indication that he is prepared for the Athenians to share or to balance power with the Thebans and the Spartans; he wants to see them both weakened and that for the advantage of the Athenians.

His clearest remarks are reserved for the Peloponnesians, the Arcadians and the Messenians. His primary motive for advocating on their behalf derives from his distrust of the Spartans. "If everyone is willing to keep the peace," Demosthenes announces, referring to the common peace

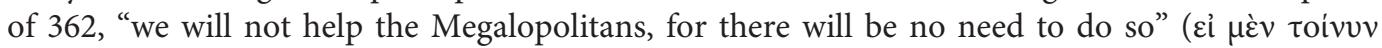

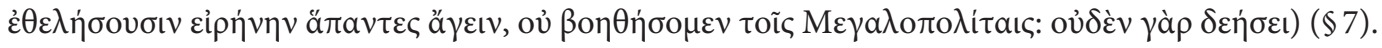
But he never really believes that the Spartans will keep the peace; they will capture Megalopolis and then Messenia, forcing the Athenians into war in support of the latter $(\$ 8)$. Beyond his fundamental misgivings about the Spartans, his advocacy for the Messenians rests on legal and practical concerns: the Athenians had given their assent to Messenian autonomy in the peace agreements of 366 and 362, and had gone even further in 355 by making a binding alliance with them. "You all know that," Demosthenes reminds the Assembly, "whether these men advise it or not, you are obligated to help the Messenians, both because of the oaths which you swore to them and because

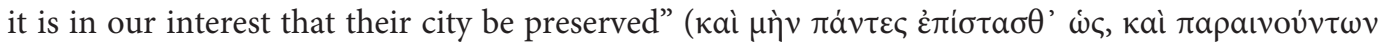

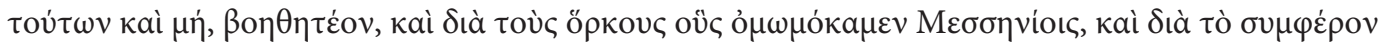

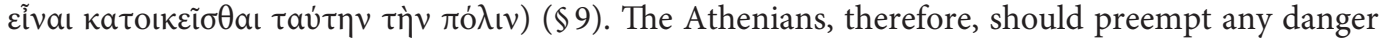

(12) Demosthenes as proxenos of the Thebans: Aeschin. 2.141-143; Trevett 1999, p. 184-202; Mack 2015, p. 114-117.

(13) 395 alliance: $I G \mathrm{II}^{2}$ 14; GHI 6; Xen. Hell. 3.5.7-16. 378 alliance: $I G \mathrm{II}^{2}$ 40; Plut. Pel. 14.1. 
posed to their own city from an encounter with a hostile Spartan army by supporting the Arcadians now rather than the Messenians later, at a disadvantage.

His reasons for supporting the Arcadians also go beyond practical concerns. Despite arguments from the pro-Spartan faction in Athens that the Arcadians should be punished for their earlier alliance with the Thebans, Demosthenes views this earlier episode as a humiliation for the Athenians. "But what they say about the Megalopolitans working with the Thebans against us is now absurd to bring up as part of charges against them, when they wish to become our friends"

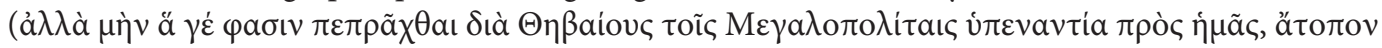

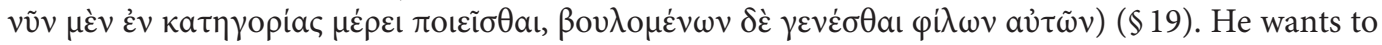
forget the past and make a new alliance with the Arcadians because, in his view, it will weaken both the Spartans and the Thebans. "It is much more honorable and more fitting that we take over the Thebans' alliances ourselves and not permit Spartan greed than that we now hesitate from saving the Thebans' allies and abandon them, but later save the Thebans all the while keeping ourselves

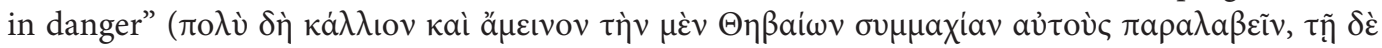

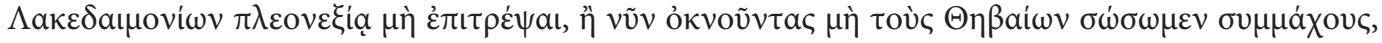

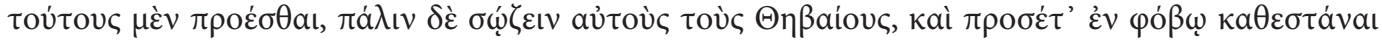

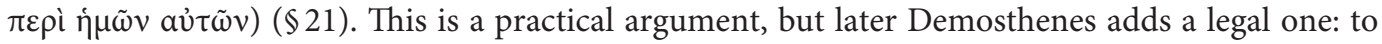
show their fealty to the Athenians and to demonstrate their renunciation of all ties to the Thebans, the Arcadians must destroy the standing stele commemorating their alliance from 370 ( $\$ 27-28$ ). It has already been mentioned that the Arcadian-Theban alliance was Demosthenes' bete noire: he saw in it the source of many of the problems facing the Athenians ever since. He supports the Arcadian alliance because it reverses the Athenian blunder in 370, obstructs the resurgence of the Spartans in the Peloponnesus, and ensures that the Athenians will not later have to defend the Messenians against an even stronger Spartan force. "I think that you ought to ponder that if you do not accept the Megalopolitans and they are destroyed and dispersed, the Spartans will immediately be stronger, but if they are saved - as has already come to pass against any hope-they will justly become firm allies of the Thebans. But if you do accept them, it will be that they are

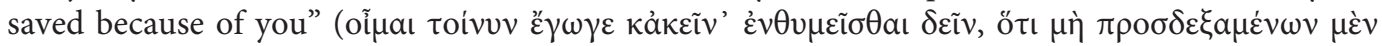

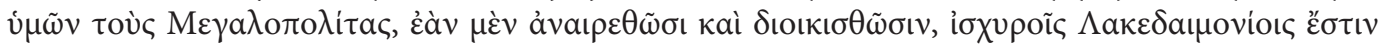

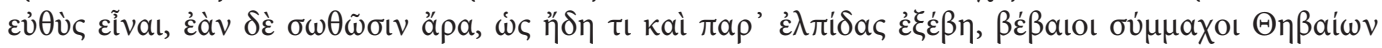

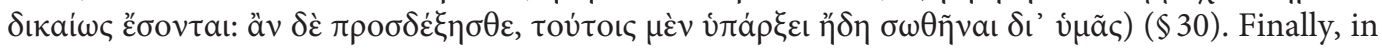
the last line of the speech, Demosthenes adds a moral reason for supporting the alliance: "I urge you not to abandon the Megalopolitans, and, in general, never to abandon the weak to the strong"

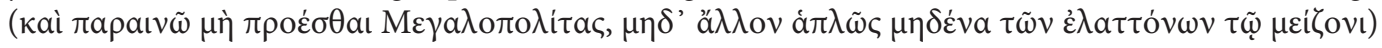
$(\$ 32)$. His advocacy for the Arcadians is based on a composite of factors and not on simple balance of power thinking.

Demosthenes succeeded in confounding rather than convincing his audience about the gist let alone the wisdom of his policy. In the end, the Athenian Assembly, no doubt puzzled by some of the convoluted and at times contradictory points of the speech, rejected the Arcadian appeal. ${ }^{14}$ Despite the dissonance in his argument, it is still possible to uncover Demosthenes' fundamental foreign policy concerns. In the midst of his patchwork of sundry positions, he puts forth three thematic justifications for the Arcadian alliance. The first is legal. Demosthenes had to show that the proposed alliance would not conflict with any of the Athenians' existing treaties. He is at pains

(14) On the incoherence of Demosthenes 16, see Ingenkamp 1970, p. 201-202; Trevett 2011, p. 276; Worthington 2012, p. 101-103. The Arcadians still received support from the Argives, Sicyonians, Messenians, and Thebans. After a few skirmishes, the Spartans made an armistice with the Arcadians (Diod. Sic. 16.39; Paus. 8.27.9-10). 
to show that the Spartans, by disregarding the peace of 362, act unjustly and illegally, whereas the Athenians respect their interstate agreements. For example, he is positive that the Athenians will honor their treaty with the Messenians, even if it means that fidelity to their legal obligations leads them to an encounter with the Spartans on the battlefield $(\$ 6-9)$. He also devotes considerable energy to showing how an alliance with the Arcadians would not conflict with the AthenianSpartan alliance of 369 , because the earlier alliance does not compel the Athenians to aid the Spartans in their attack against Megalopolis, nor does the proposed alliance require them to aid the Arcadians in an offensive attack against the Spartans $(\$ 14)$. Likewise, Demosthenes expects the Arcadians, as prospective allies, to avoid any trace of illegality by revoking their earlier alliance with Thebes, signified by the destruction of the alliance stele standing in Megalopolis $(\$ 27)$. To Demosthenes, his policy adhered to all legal regulations.

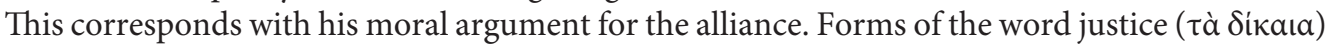
appear thirteen times in the speech, and injustice ( $\tau a ̀$ ó $\delta ı \alpha \alpha)$ nine times. ${ }^{15}$ Early in the speech, he instructs his audience to "always determine what is tà Síkaı and do it" (\$10). Since what the Thebans have done in central Greece and what the Spartans plan to do in the Peloponnesus is unjust, the Athenians, he insists, must act on behalf of the Arcadians-it is justice.

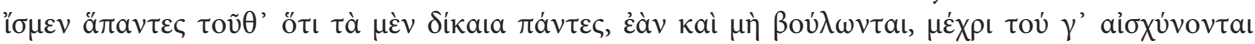

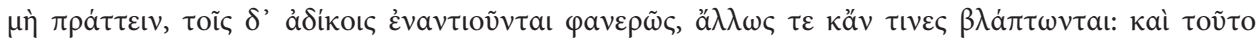

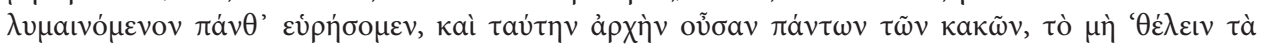

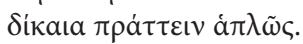

We all know that all are ashamed not to do what is just, up to a point, even if they do not wish it, and that they are openly against injustice, especially if someone is injured. We shall find that that which ruins everything and is the root of all evils is simply being unwilling to act justly $(\$ 24)$.

Demosthenes argues that Athenian support for the smaller Peloponnesian and Boeotian cities under

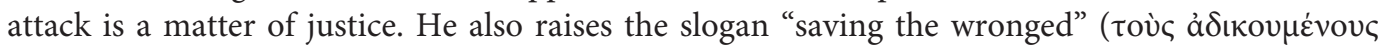
$\sigma \omega \dot{\zeta}(\varepsilon \mid v)$ - a common expression in fourth-century literature to justify interstate interventioninsisting that it was the purpose for which the Athenians helped the Thebans in 378, the Spartans in 369, and the Euboeans in 357 ( $\$ 14-15) .{ }^{16}$ Alleging this to have been a consistent aim of Athenian policy in the past, he poses it as a key reason for accepting the Arcadian alliance. The final lines of the speech reiterate this:

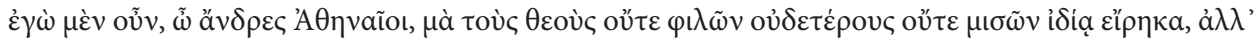

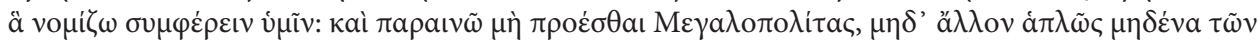

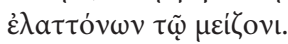

Therefore, men of Athens, by the gods, I have spoken, with no affection or hatred in me for either side, what I consider advantageous to you; I urge you not to abandon the Megalopolitans, and, in general, never to abandon the weak to the strong $(\$ 32)$.

In addition to legal and moral considerations, Demosthenes also takes into account the political advantages this alliance would bring to the Athenians. Justice is always a priority for any decision the Assembly should make, but he adds that "you should consider at the same time how this might

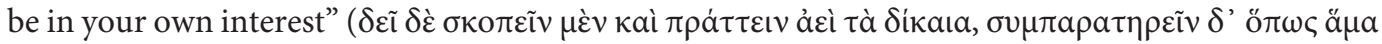

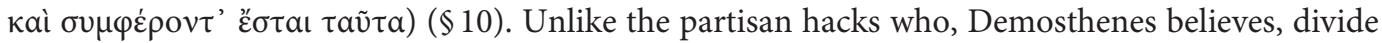
the Athenian citizenry, the younger orator claims to hold a policy entirely in the national interest. His first such concern is the recapture of Oropus, indicated by the fact that in this short speech he raises it four times $(\$ 11,13,16,18)$. Recovering control of Oropus and the reconstruction of

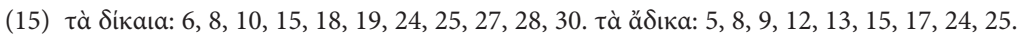

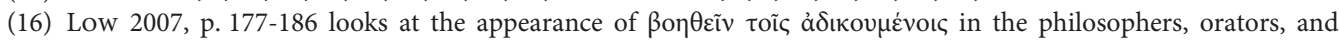
historians of the fourth century. 
Boeotian cities would insulate the Athenians from any possible attacks from the Thebans. Yet, that is secondary to his other national interest concern: security from the Spartans ( $\$ 18)$. If the Spartans grow stronger, it would be a threat to the Athenians because, first, it will draw the Athenian army into the Peloponnesus in defense of their treaty obligations with the Messenians and, second, as Demosthenes fears, the Spartans will one day turn against Athens, in which case the Athenians will need the Thebans as an ally $(\$ 20-22)$. A few sentences later, however, in his typical contradictory fashion, he advises help for the vulnerable Boeotians against the Thebans in the same way that he advises help for the Peloponnesians under assault from the Spartans (\$25-26). As he talks he fails to straighten out the kinks in his conflicting suggestions, but in his conclusion he is emphatic that

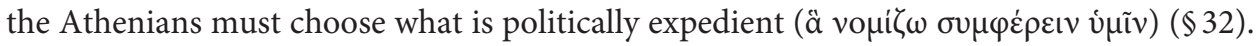

Demosthenes' speech comprises a number of justifications for the new alliance and for an increased involvement for the Athenians in interstate affairs, but as part of this he does not include a clear balance of power strategy. If one returns to $\$ 4-5$, in which Demosthenes lays out his fundamental foreign policy principles, there is no indication that he is interested in preserving the status quo, or a balance of power on the mainland. Instead, as he explains in the rest of the speech, he seeks to revise the current geopolitical arrangements, to create an imbalance of power, in the Athenians' favor. He wants to see the power of the Thebans and the Spartans diminished. Robin Lane Fox smartly calls this a strategy of "balance of weakness." ${ }^{\text {17 }}$ But more than just political ambitions, Demosthenes' case rests also on legal and moral considerations-even if he has difficulty synthesizing them coherently. As a political theory, therefore, Demosthenes did not acknowledge balance of power. Michael Sheehan, who begins his history of the balance of power by declaring it "one of the most important concepts in history," concedes, when he discusses Demosthenes 16 and the Greeks, that "while one can detect behaviour in the ancient Greek system which is analogous to balance of power behaviour, it was not self-consciously done for that purpose."18 If the actors themselves were unaware of the presence of a balance of power, one should question how germane it is as an interpretative theory for ancient Greek interstate activity. How is it, then, that many today continue to highlight in Demosthenes 16 the alleged influence of balance of power but ignore the other non-political factors?

\section{THE GENEALOGY OF “BALANCE OF POWER"19}

The short answer is that balance of power ideology has such deep roots in western scholarship that today it is easy to mistake it for an ahistorical maxim instead of an anachronistic metaphor. Ancient Greek did not have a word or phrase for balance of power. The term originated only five hundred years ago, when European political thinkers began to explain the constant warfare between the discordant city-states of Renaissance Italy. ${ }^{20}$ Once fully articulated, balance of power became axiomatic, the guiding diplomatic principle for the warring nation-states of Europe in the coming centuries. In the English-speaking world, its most influential exponent was the Scottish

(17) LANE Fox 1997, p. 181

(18) Sheehan 1996, p. 1, 27. Wolpert 2001, p. 79 and Little 2007b, p. 47-66 object that the Greeks did not understand or have a lexicon for international structures.

(19) After completion of this article, the author discovered Morten Skumsrud Andersen's $2016 \mathrm{PhD}$ thesis (The London School of Economics and Political Science) titled A Genealogy of the Balance of Power.

(20) The first time that a form of balance of power ("L'équilibre européen") appears in print is in Philippe de Commynes' Mémoires (1524). Origins of balance of power: Sheehan 1996, p. 24-52; Haslam 2002, p. 89-127; Kaufman, Little, and WOHLFORTH 2007. 
philosopher David Hume, whose 1752 essay "On the Balance of Power" attempted to answer the question "whether the idea of the balance of power be owing entirely to modern policy, or whether the phrase only has been invented in these latter ages" ${ }^{21}$ [emphasis in the original]. Convinced that balance of power was a natural law, Hume begins his essay with the assumption that the ancient Greeks were cognizant of it-"the maxim of preserving the balance of power is founded so much on common sense and obvious reasoning, that it is impossible it could altogether have escaped antiquity." Through anecdotal evidence-anti-Athenian alliances during the Peloponnesian War and the Athenian-Theban alliances in the fourth century, for example-Hume concludes that the Greeks actively sought to preserve a balance of power. He points to Demosthenes 16 for evidence: "Whoever will read Demosthenes's oration for the Megalopolitans, may see the utmost refinements on this principle, that ever enter'd into the head of a Venetian or English speculatist." But this is all he says in this essay about Demosthenes; it is an assertion, without any substance. In fact, after he refers to Demosthenes and then the Greek alliance against Philip of Macedon, Hume contradicts himself, in Demosthenic fashion, by admitting that "the Grecian wars are regarded by historians as wars of emulation rather than of politics; and each state seems to have had more in view the honour of leading the rest, than any well-grounded hopes of authority and dominion." In other words, after alleging that the balance of power regulated the interstate activity of ancient Greece, Hume points to glory as the Greeks' primary motive. Moreover, in raising Venetian and English speculatists, Hume betrays the balance of power's anachronism. Despite his strong claims to its antiquity, balance of power is a modern European concept that would be foreign to the ancient Greeks such as Demosthenes. In writing this essay, Hume had his contemporary context in mind and expected that the balance of power would exert its moderating influence upon the European affairs of his day just as it did, so he thought, for a time on the Greek world. ${ }^{22}$

The Napoleonic Wars disrupted the Westphalian stability of Europe and challenged the relevance of balance of power, but during the subsequent long nineteenth century, when Conservative statesmen, especially in Britain, touted balance of power as the panacea to the disorder in Europe, Hume's association of balance of power with Demosthenes 16 became communis opinio. A few examples from prominent scholars of the period should suffice. The British Whig statesman Henry Lord Brougham began his own 1803 essay "Balance of Power" by recognizing his esteemed predecessor: "Mr. Hume, so far as we know, is the first who stated this point [balance of power's presence in antiquity], in an Essay replete with acute observation, and distinguished by accuracy of classical illustration... and the orations of Demosthenes (particularly the famous speech "Pro Megalopolitanis") contain some discussions of the most delicate parts of the theory." The German historian Arnold Schaefer wrote in Demosthenes und seine Zeit that Demosthenes and his contemporaries understood that for die Wiedergeburt Athens they needed to create ein Gleichgewicht der Macht in the Greek world. In Demosthenes and the Last Days of Greek Freedom, 384-322 B.C., Arthur Pickard-Cambridge uses the phrase "balance of power" three times in his comments on Demosthenes 16. In his famous political biography of Demosthenes, Werner Jaeger looked to Lord Brougham who "finds in this oration [Demosthenes 16] the earliest development of that supreme principle which England has consistently applied for centuries in her dealings with the states of continental Europe and which has in large measure enabled her to build up her own great authority: the principle of the balance of power [emphasis in original]." ${ }^{23}$ Thus, Hume's original assertion was repeated and reinforced.

(21) Hume 1987, p. 339-348.

(22) On Hume's political uses for balance of power, see WhELAN 1995, p. 315-332.

(23) Brougham 1872, p. 1-50; Schaefer 1856, p. 465-471; Pickard-Cambridge 1914, p. 131-137, 165, n. 1; Jaeger 1938, p. 43, 88. 
In the mid- to late twentieth century, after the two world wars and the beginning of the Cold War, when international relations emerged as an academic discipline of its own, scholars, in the English-speaking world at least, began to expound upon Hume's claim with a greater degree of theoretical refinement and a greater emphasis on power politics. New works on alliance dynamicsHans Morgenthau's Politics Among Nations (1948), George Liska's Nations in Alliance (1962), and Kenneth Waltz's Theory of International Politics (1979), to name a few-grounded their studies in the putative iron laws of balance of power. These works are core texts for the school of realism, the dominant explanatory international relations model of the twentieth century and today, which views the world in a condition of endemic conflict and competition. Every other state, therefore, is a potential rival and not to be trusted. In this atomistic scenario, states, acting according to pragmatism and self-interest, only reluctantly enter into alliances and then only for political or military purposes. Realists consider alliances to be negative agreements; as Liska famously declared, "alliances are against, and only derivatively for, someone or something." ${ }^{24}$ Reducing geopolitical activity to balance of power and power politics, realists dismiss ideological or moral concerns as irrelevant to the actual operation of international affairs.

This realist narrative of power dynamics in balance of power, with abundant anecdotal and theoretical support from modern European history, is what has permeated recent scholarship of classical Greece. Piero Treves and Robin Seager, for example, make great use of balance of power in their respective publications. The concept saturates Frank E. Adcock and D. J. Mosley's Diplomacy in Ancient Greece. In two articles devoted specifically to classical Greek alliances, Barry Strauss argues that, except in very few cases, the Greeks routinely entered into alliances to maintain a balance of power. Similar assessments can be found throughout the works of Philip Harding ("balance-of-power politics was Athens' preferred method of dealing with the Greek states on the mainland"), Arthur Eckstein (alliances are results of "shifting and complex balances of power between ferociously independent polities"), Peter Hunt ("balance-of-power considerations often required shifts of alignment even at the expense of treaty obligations and the friendships they often formalized"), and others. ${ }^{25}$ It is unsurprising, therefore, to find modern studies on Demosthenes' political policies echoing these views. On die Außenpolitik Athens in the 350s, Gustav Adolf Lehmann follows Jaeger's praise of Lord Brougham:

Demosthenes' Eintreten für eine weitsichtige und dabei strikt an den langfristigen Interessen Athensals überlegener Hegemonie- und Seemacht im Ägäisraum-orientierte Gleichgewichtspolitik hat der Megalopoliten-Rede unter anderem die Bewunderung von Henry Lord Brougham (1778-1868, Lordkanzler 1830-1834), einem bedeutenden englischen Politiker und Publizisten aus der <Schule> der klassichen balance of power-Politik, eingetragen. [emphasis in the original]

Ian Worthington, whose overall appreciation of Demosthenes' politics differs from Lehmann's, follows suit in seeing a connection between Demosthenes and the modern development of balance of power:

In looking to the long-term interests of Athens, Demosthenes pointed out that Sparta's ascendancy in the Peloponnese at Theban expense affected the balance of power in Greece between Sparta and Thebes. Demosthenes' claim was a precursor of the modern balance of power argument, first expounded by the British politician Lord Brougham in the nineteenth century. ${ }^{26}$

(24) Morgenthau 1948; Liska 1962, p. 12; Waltz 1979, p. 102-128. Nexon 2009, p. 330-359 reviews more recent scholarship.

(25) Treves 1970; Seager 1974, p. 36-63; Adcock and Mosley 1975, p. 137; Strauss 1991, p. 189-210; 1997, p. $127-$ 140; EcKstein 2006, p. 75-76 (cf. 2008); Hunt 2010, p. 162; Christ 2012, p. 118-125; Harding 2015, p. 36-37.

(26) Lehmann 2004, p. 81; Worthington 2012, p. 100. Carlier 1990, p. 81-83: "Le Pour les Mégalopolitains était particulièrement admiré de David Hume, qui y voyait (en 1752) la première formulation du principe de balance of power (équilibre des puissances) cher à la diplomatie britannique." [emphasis in the original] 
Despite the certainty in these pronouncements, did Demosthenes in fact, as Hume and Lord Brougham maintained, recognize balance of power's invisible hand in alliances? Did he, as realists suppose, take into account systemic features and acknowledge the potential of alliances to correct imbalances in the interstate structure? After reexamining Demosthenes' speech, this article answers these questions in the negative. In fact, since the end of the Cold War, balance of power has faced increasing criticism from political scientists who have developed alternative models to the traditional paradigm. ${ }^{27}$ Randall Schweller has popularized "bandwagoning," which explains the situations when small powers align with (rather than balance against) a threatening power. Glen Snyder makes a case that alliances, formal expressions of informal alignments, "are often very durable; as relationships they are certainly more durable than the interactions by which they 'form and dissolve." Constructivists reject the view of a static international structure based on balance of power, and instead see alliances as products of historical interactions and social relations between states. $^{28}$

At the same as these alternative views have come to light, scholars of ancient Greece have become increasingly open to new ways of interpreting ancient interstate activity. Some reject the reductionistic view that Demosthenes' reason for accepting the Arcadian alliance was only a matter of power politics and balance of power, the view which this article has also disputed. Douglas MacDowell, for example, stresses the non-political factors in the orator's thinking: "This emphasis on morality in foreign policy is the most significant feature of the speech For the Megalopolitans." Iris Samotta, following Stephen Walt's balance-of-threat model, a nuanced modification of balance of power, in her interpretation of Demosthenes' geopolitics, views Athenian alliances of the midfourth century as responses to perceived aggression from other states. Wolfang Will admits that "sicherlich ist Demosthenes nicht der Erfinder dessen, was jetzt „Balance of Power“ gennant wird und wofür ihm seit der frühen Neuzeit Bewunderung von Staatsmännern und Historiken gezollt wurde." Instead Will thinks that the speech is designed only to display the young Demosthenes' rhetorical prowess ("Demosthenes hielt eine Rede, die seine politischen Fähigkeiten zeigen sollte, und das tat sie"), and that therefore the vote against the alliance was not a defeat for Demosthenes personally. Most recently, Patrice Brun, although he is dealing with Demosthenes' strategy against Philip not the Spartans and Thebans, disputes the presence of balance of power in the Athenian's foreign policy: "Il ne s'est guère préoccupé de mener une politique d'équilibre des puissances, de 'balance of power' qui aurait permis, peut-être, de rendre les progrès de Philippe plus résistibles." ${ }^{29}$ This, as this article has argued, could be said just as well for the position of Demosthenes 16.

Indeed, this article has demonstrated how in his advocacy for an alliance with the Arcadians Demosthenes does not present a simple foreign policy calculus based on balance of power. $\mathrm{He}$ does not even present a coherent and consistent case, advocating paths of competition and

(27) As early as 1836, Richard Cobden, the Liberal MP, in his own "Balance of Power" (Cobden 1903, p. 194-216), a critique of the British foreign policy of his time, wrote that there was no basis in the primary sources for Hume's and Brougham's association of balance of power with Demosthenes. Cobden's views, however, were polemical, influenced by contemporary politics just as much as Hume's reading of balance of power, and largely forgotten today.

(28) SChWeller 1994; SNyder 1997. Constructivism: Onuf 1989; Wendt 1992, p. 391-425; 1999. Lebow 2007, p. 351378 and Zumbrunnen 2015, p. 296-312 employ constructivism in their studies of classical Greece. Like constructivism, the peer-polity interaction model emphasizes "structural homologies," products of concrete and symbolic interstate interactions (MA 2003, p. 9-39; MACK 2015, p. 190-232). For critiques of balance of power from a World History perspective, see PAUL, ForTMAN, and WirTZ 2004; LitTLE 2007a.

(29) MacDowell 2011, p. 210; SAmotta 2010, p. 1-2, 37-39 (cf. Walt 1987); Will 2013, p. 54; Brun 2015, p. 140. WALt 2018 promotes "offshore balancing," a strategy of employing others to check potential threats. There are other broader studies of ancient Greek interstate relations that downgrade the alleged impact of warfare and emphasize un système d'États pluraliste (Giovannini 2007) and a "normative framework" governing interstate conduct (Low 2007). 
collaboration with political rivals, and stressing at one point political advantage and at another the justice of supporting weak states. His arguments support an imbalance of power, to the Athenians' advantage, rather than a balance of power with other leading states. Because the latter terminology has become entrenched in the scholarship of international politics ever since David Hume's 1753 essay, scholars today tend to view Demosthenes' policy in terms that resemble modern politics rather than the ancient context. Taking Demosthenes 16 as a whole, however, one finds a composite argument that incorporates, albeit ineffectually, factors of political interest with those of morality and justice. Although some of this was pretense and not to be taken as altruism, nevertheless the speech illustrates the importance of both political and non-political features in the orations presented before the Athenian Assembly in the fourth century.

Nicholas D. CROss

Illinois Mathematics and Science Academy

\section{Bibliography}

Adcock, F. E., Mosley, D. M., 1975, Diplomacy in Ancient Greece, London.

Brougham, H.P., 1872, Works of Henry Lord Brougham, vol. VIII: Dissertations-Historical and Political, Edinburgh.

Brun, P., 2015, Démosthène - Rhétorique, pouvoir et corruption, Paris.

Buckler, J., 1980, The Theban Hegemony, 371-362 B.C., Cambridge, Mass.

Carlier, P., 1990, Démosthène, Paris.

Christ, M., 2012, The Limits of Altruism in Democratic Athens, Cambridge.

Cobden, R., 1903, The Political Writings of Richard Cobden, vol. 1, London.

Cross, N., 2017, "The Imitation Game: Interstate Alliances and the Failure of Theban Hegemony in Greece”, Journal of Ancient History 5, p. 280-303.

Dillery, J., 1995, Xenophon and the History of His Times, New York.

Ducat, J., 2010, “The Ghost of the Lakedaimonian State," in A. Powell, S. Hodkinson (eds.), Sparta: The Body Politic, Swansea, p. 183-210.

Eckstein, A., 2006, Mediterranean Anarchy, Interstate War, and the Rise of Rome, Berkeley.

Eckstein, A., 2008, Rome Enters the Greek East: From Anarchy to Hierarchy in the Hellenistic Mediterranean, 230-170 B.C., Malden, MA.

Giovannini, A., 2007, Les relations entre états dans la Grèce antique du temps d'Homère à l'intervention romaine (ca. 700-200 av. J.-C.), Stuttgart.

Harding, P., 2015, Athens Transformed, 404-262 BC: From Popular Sovereignty to the Dominion of the Elite, New York.

Haslam, J., 2002, No Virtue Like Necessity: Realist Thought in International Relations since Machiavelli, New Haven.

Hume, D., 1987, Essays: Moral, Political, and Literary, New York.

Hunt, P., 2010, War, Peace, and Alliance in Demosthenes' Athens, New York.

Ingenkamp, H. G., 1972, "Die Stellung des Demosthenes zu Theben in der Megalopolitenrede”, Hermes 100, p. 195-205.

Jaeger, W., 1938, Demosthenes. The Origin and Growth of His Policy, Berkeley.

JeHne, M., 1994, Koine Eirene: Untersuchungen zu den Befriedungs- und Stabilisierungsbemühungen in der grieschischen Poliswelt des 4. Jahrhunderts v.Chr, Stuttgart. 
Kaufman, S. J., Little, R., Wohlforth, W.C., 2007, The Balance of Power in World History, New York. Kelly, D.H., 1980, "Philip II of Macedon and the Boeotian Alliance”, Antichthon 14, p. 64-83.

Lane Fox, R., 1997, “Demosthenes, Dionysius and the Dating of Six Early Speeches”, Classica et Mediaevalia 48, p. 167-203.

Lebow, R. N., 2007, Coercion, Cooperation, and Ethics in International Relations, New York.

Lehmann, G. A., 2004, Demosthenes von Athen: ein Leben für die Freiheit, München.

LiskA, G., 1962, Nations in Alliance: The Limits of Interdependence, Baltimore, Md.

Little, R., 2007a, The Balance of Power in International Relations: Metaphors, Myths and Models, Cambridge. Little, R., 2007b, “The Greek City-States in the Fifth Century BCE: Persia and the Balance of Power," in S. J. Kaufman, R. Little, W.C. Wohlforth (eds.), The Balance of Power in World History, New York, p. 47-66.

Low, P., 2007, Interstate Relations in Classical Greece: Morality and Power, Cambridge.

MA, J., 2003, "Peer Polity Interaction in the Hellenistic Age", Past and Present 180, p. 9-39.

MacDowell, D., 2010, Demosthenes the Orator, Oxford.

Mack, W., 2015, Proxeny and Polis: Institutional Networks in the Ancient Greek World, Oxford.

Morgenthau, H., 1948, Politics Among Nations: The Struggle for Power and Peace, New York.

Nexon, D., 2009, “The Balance of Power in the Balance”, World Politics 61, p. 330-359.

Onuf, N., 1989, World of Our Making: Rules and Rule in Social Theory and International Relations, Columbia, SC.

Paul, T. V., Fortman, M., Wirtz, J. J. (eds.), 2004, Balance of Power: Theory and Practice in the 21st Century, Stanford.

Pickard-Cambridge, A., 1914, Demosthenes and the Last Days of Greek Freedom, 384-322 B.C., New York and London.

Ryder, T.T. B., 1965, Koine Eirene: General Peace and Local Independence in Ancient Greece, London.

Samotta, I., 2010, Demosthenes, Tübingen.

Schachter, A., 2016, Boiotia in Antiquity: Selected Papers, Cambridge.

Schaefer, A., 1856, Demosthenes und seine Zeit, vol. 1, Leipzig.

Schweller, R. L., 1994, "Bandwagoning for Profit: Bringing the Revisionist State Back In", International Security 19, p. 72-107.

Seager, R., 1974, “The King's Peace and the Balance of Power in Greece, 386-362 B.C.", Athenaeum 52, p. 36-63.

Sheehan, M., 1996, Balance of Power: History and Theory, New York.

SNyder, G., 1997, Alliance Politics, Ithaca.

Strauss, B., 1991, "Of Balances, Bandwagons, and Ancient Greeks," in B. Strauss, R. N. Lebow (eds.), Hegemonic Rivalry: From Thucydides to the Nuclear Age, Boulder, CO, p. 189-210.

Strauss, B., 1997, “The Art of Alliance and the Peloponnesian War," in C.D. Hamilton and P. Krentz (eds.), Polis and Polemos: Essays on Politics, War, and History in Ancient Greece in Honor of Donald Kagan, Claremont, p. 127-140.

Treves, P., 1970, Balance of Power Politics in Classical Antiquity, Moscow.

Trevett, J., 1999, “Demosthenes and Thebes”, Historia 48, p. 184-202.

Trevett, J., 2011, Demosthenes, Speeches 1-17, Austin, TX.

Walt, S. M., 1987, The Origins of Alliances, Ithaca.

Walt, S. M., 2018, The Hell of Good Intentions: America's Foreign Policy Elite and the Decline of U.S. Primacy, New York.

Waltz, K., 1979, Theory of International Politics, Reading, Massachusetts.

Wendt, A., 1992, “Anarchy is what States Make of it: The Social Construction of Power Politics”, International Organization 46, p. 391-425. 
Whelan, F. G., 1995, “Robertson, Hume, and the Balance of Power”, Hume Studies 21, p. 315-332.

Wight, M., 1966, “The Balance of Power," in H. Butterfield, M. Wight, H. Bull (eds.), Diplomatic Investigations: Essays in the Theory of International Politics, London, p. 149-175.

Will, W., 2013, Demosthenes, Darmstadt.

Wolpert, A., 2001, “The Genealogy of Diplomacy in Classical Greece”, Diplomacy \& Statecraft 12, p. 71-88.

Worthington, I., 2012, Demosthenes of Athens and the Fall of Classical Greece, Oxford.

Zumbrunnen, J., 2015, "Realism, Constructivism, and Democracy in the History," in C. Lee, N. Morley (eds.), A Handbook to the Reception of Thucydides, Malden, MA, p. 296-312. 